\title{
Localizing Transnationalism: A Struggle for Women's Employment Rights a Narrative from Sudan
}

\author{
Mawahib Ahmed Bakr \\ Hamad Bin Khalifa University \\ Qatar
}

\begin{abstract}
Under the banner of protecting Sudanese culture and religion from the West, the Islamic government in Sudan represented by the Governor of Khartoum issued the Decree Number 84 for the year 2000 on September 4th, 2000 in which he banned women's work in gas stations, restaurants, and hotels. Women's employment rights that were accomplished in the 1950s were endangered. This paper engaged with the narratives of the Sudanese women who struggled against this decision. These women used and adapted the International UN documents and utilized their transnational ties in support of their cause. Their transnational campaign succeeded in getting the international condemnation by Human Rights Watch to this Decree on September 8, 2000 and it was put on hold by the Constitutional court in Khartoum. I argue that this historical struggle of women in Sudan highlights the importance of considering the local context as a site of knowledge production that is capable of supporting women's transnational resistance worldwide.
\end{abstract}

Keywords: Transnationalism, feminism, women's struggle, employment rights, Sudan

The transnational era has brought about new avenues for women's activism and new challenges, which threaten not only the possibilities of achieving more rights but also maintaining those that are already accomplished. Women in Sudan achieved their right to employment in the 1950s as part of their struggle alongside nationalists for Sudan's independence. In the 1960s, they fought for payment equal to that of men, because at the time, women received only one third of a man's salary, even if they were doing the same kind of job. They received this right in 1973, along with other labor rights of maternity leave and pension. All these rights consolidated women's existence in public life and were considered to be the main accomplishments of the pioneers of the women's movement in Sudan. However, on September 4th, 2000, the Governor of Khartoum turned back the clock on women's rights by issuing Decree Number 84 for the year 2000, in which he banned women's work in gas stations, restaurants, hotels, and other public service sectors. This Decree was issued with clear directives to the police and security forces to put this decision into immediate effect. Under the banner of protecting Sudanese culture and religion from the West and with the support of the Islamic government in Sudan, women's rights were jeopardized.

Sudanese women collaborated to fight for their rights at both local and international levels by taking a direct lead and using international documents, agreements, and conventions as tools to sustain women's rights and benefit from their international and transnational ties to support their case. The fact that this Decree received international condemnation by Human Rights Watch on September 8, 2000 and was put on hold by an internal court in Sudan indicated that the campaign led by women for their rights was a success. This paper explores this historical event as a case study referencing the narrative of these Sudanese women activists and documenting their views. The ways in which women in Sudan have used and adapted the International UN documents and their transnational ties (including NGOs, UN offices, and the support of donors and foreign embassies) to support their rights are informative and represent an essential and integral part of transnationalism. I maintain the importance of a consideration of the local context as a site of knowledge production especially within the framework of transnationalism and transnational processes. I argue that such consideration may help to create knowledge, which is locally produced but capable of supporting the overall transformative feminist project.

\section{Theoretical Reflections}

Feminists have used the term "transnational" in many ways. Feminist literature (Desai, 2002; Ferree \& Tripp, 2006; Khagram \& Levitt, 2008; Lee \& Shaw, 2010; Moghadam, 2005; Naples, 2002; Tripp , Casimiro, Kwesiga, \& Mungwa, 2009) celebrates and explores the opportunities provided by the United Nations (UN), the role of the UN International Women's conferences, and International and Local Non-Governmental Organizations (NGOs) in support of women's local and international activism. Transnational activism includes, in addition to international conferences, the growth of transnational women's movements and civil society groups, as well as linkages within transnational civil society and the flow of resources to support women's organizations. 
Transnationalism refers to the linkages between global women's networks and women's local groups as well as the activisms and relationships among the variety of local women's groups. Chowdhury argued that the term transnational "refers to women's organizing that recognizes, in theory and in practice, the multilayered power relations shaping women's struggles in North-South as well as South-South contexts" (Chowdhury, 2011, p. 7). Chandra Mohanty and Jacqui Alexander (2010) provide a broad definition for the "transnational" emphasizing its difference from "global feminism." For them, transnationalism considers the importance of the different geographical locations, women's difference, and unequal power relations in shaping women's experiences. It also pays attention to the different international impacts of the economic, political, and ideological processes. However, until recently little attention has been paid to local women's groups and/or networks involved in transnational activism and the local impacts of such engagements on the different dynamics of women's activism (Alvarez, 2009; Basu, 2000; Chowdhury, 2011; Friedman, 2001; Tripp, 2006). Friedman calls such local impacts "transnationalism reversed" and refers mainly to the local activism of women in Venezuela in preparation for the international women's conferences in Nairobi and Beijing. She argues that both local conditions and international opportunities come together to shape women's local activism in different ways (Friedman, 1999, p. 385). Alvarez maintains that both the national and the transnational "are mutually constitutive" she refers to down-top activism on part of local women to pressure for their rights (Alvarez, 2000, p. 32). However, she acknowledges the dynamics of power relations involved which may lead to contradictory and clashing impacts among different women's groups. Further, transnational feminists' praxis allows for the contextualization of women's experiences and agency with a consideration of the oppression of their daily lives (Naples, 2008, p. 514). Chowdhury highlights the "uneasy alliances" between women activists and the local and international development and human rights organizations against acid violence in Bangladesh in the mid-1990s. She indicates the importance of the contradictions, tensions, hierarchal relations, and the adverse "unintended effects" of "transnationalism reversed," as well as calling for a critical understanding of this "reversed women's activism" with the hope of building "more just feminist alliances" (Chowdhury ,2011, p. 8).

I argue that transnational feminist practices do not only refer to alliances among feminists across borders, but also include coalitions among different women's groups across the divides of ethnicity, religion, region etc. In this paper, I emphasize transnationalism as a mutual linkage that occurs not only between global networks and women's local groups but also among the variety of local women's groups, i.e., transnationalism at two levels-"local/international" and "local/local" - in an attempt to acknowledge the efforts of building "transnational alliances" among women's different groups at local sites. Furthermore, these transnational impacts are not only shaped by the local contexts, but are dealt with differently by different women's groups in local sites. A wide scope of "transnationalism reversed," or the "flip side" of transnationalism, to use Alvarez's (Alvarez ,2000, p. 32) words, is to include references not only "home activism" between local women's different groups and international organizations and/or international ties, but also to consider women's activism among different women's groups at local sites. It is also crucial to consider efforts at creating solidarity and "complicated" alliances among local different women's groups as part of this "transnationalism reversed." "Transnationalism reversed" represent the new era of women's activism in Sudan. This era is led by the Sudanese Women activists in Community Organizations and in Non-Governmental Organizations (NGOs). This group of women has benefited from the establishment of women's international agencies and women's desks at official ministries and in the UN offices. Some of them led projects on violence against women, women's legal concerns, women's income generating projects, gender awareness, etc. They have come together around women's issues regardless of their differences. I argue that in the case of Sudan, such "complicated transnational alliances" have been achieved at both levels: local/local (i.e., Sudan), and local/transnational, (i.e., across borders).

Historically, the preparations for this transnational era began long ago with the decision of the women activists in the early 1950 s to extend their relations with their counterparts regionally and internationally. The Women Union (WU) established relationships with the Union of Arab Women (UAW), the African Women's Congress (AWC), and the International Democratic Union for Women (IDUW). The WU Secretary General Fatma Ahmed Ibrahim participated in the activities of the IDUW as confirmed by El-Amin, "In 1954, Fatma joined the activities of the Democratic Union secretly as it was forbidden in those days in London, Paris and Berlin" (El-Amin, 1994, p. 17). This trend continued in the years afterwards, despite the fact that the government of Sudan due to its poor relationship with the Soviet Union and Communist countries during that period disallowed such communication.

In 1957, women delegates from Sudan participated in the Conference of Women's Rights in Moscow, headed by Khalda Zaher, Sudan's first female medical doctor (Badri. H, 2002, p. 128). In the 1970s, one of the objectives of the Union of Sudanese Women (SWU) was to collaborate with UN organizations, as well as regional ones. The President of the SWU, Nafisa Ahmed Elamin, was elected Assistant Secretary General to the Secretary General of the General Union of Arab Women. 
The SWU participated in the International Women's Year and the First Women's Conference in Mexico, as well as in the second conference in Copenhagen. They also participated in the execution of the resolutions of conferences in the national field (El-Amin, 1994, p. 30-31).

The UN Women's Decade, which ran from the mid-1970s up to 1985, witnessed an enormous increase in the activities of women inside Sudan as more connections were established with international organizations, and "the number of civil society groups and NGOs increased dramatically in Sudan especially women's organizations" (Dawalbaiet, 2007, p. 13). Also during this period, UN agencies and women's desks or departments at both these agencies and at some embassies - especially the Embassy of the Netherlands - played a prominent role in supporting women leaders in civil service and the academy by providing support for women's projects and scholarships for women to study abroad (Badri, 2008, p. 51).

During the democratic era (1985-1989), the liberty to form organizations plus the war and drought in the west of Sudan led to an increase in the numbers of NGOs with a mandate to address the needs of displaced people. Several local women's organizations were also founded. Badri confirms that, "In 1986 during democracy sixteen women's NGOs were registered" (Badri, 2008, p. 51). Several local voluntary women's organizations such as El Fanar, El Manar, the Gender Center for Research and Training, and Mutaunat, other women's projects were established in other Sudanese states such as Gadarif, Kassala in East Sudan, El Obied, Darfur in West Sudan, and the South plus women's secretariats positions were established in political parties (Nouh \& Badri, 2008, p. 172).

These women's organizations engaged in different projects for women that focused on development, human and legal rights, awareness-raising, capacity-building, advocacy on issues of violence against women, reproductive health, democracy, and peace. Women working for these organizations joined different training programs on gender equity and women's development; this enhanced their skills, levels of professionalism, and provided them with much knowledge on dealing with external donors, project development, evaluation, and reporting. Badri confirms that, "Women responsible for these offices received training, attended international meetings and are expected to report to the international community on women's status in Sudan. They are expected to come up with plans of action and develop policy frameworks for women's empowerment and gender equality" (Badri ,2008,p. 58), Furthermore, the multiplicity of activities handled by these activist women has had the dual impact of strengthening their own capacities while at the same time responding to women's needs at the grassroots level. This was demonstrated by the way these women responded to the Governor's Decree of 2000.

\section{Methodology}

I have interviewed 23 of the women who participated in this struggle and who worked with local and international organization; I used qualitative research methods including in-depth, semi-structured, and open-ended interviews. I selected these qualitative research tools because of their capacity to access information about women's experiences, activism, and the challenges they face. Feminist transnationalist research forges an adherence to positionality, reflexivity, and accountability on part of the researcher (Swarr \& Nagar 2010, p.5). The open-ended nature of questions created a sense of engagement between the research participants and me as a researcher. It also enabled me to deal with shifting contexts, fluidity of positionalities, and to grasp multiple meanings in changing contexts. They reflected on their experiences as active agents in changing this Decree. Stories of these women represent not only their memory but "the story teller is the living memory of her time, her people" (Trinh, 1989, p.125). These women reflect on how they interact with their local living conditions, how this interaction is translated on their decision to use the international documents and their transnational ties to support their struggle against this government Decree represent.

\section{The Narrative}

On Sep.4th /2000 this Decree was issued with a recommendation to those service providers to hire those women in other places and with clear directives to the authorities of social affairs, local governments, and the police and security forces to put this decision into immediate effect. It was circulated to all government newspapers. The justification for this Decree was presented in its foreword. It maintained that, this is in consideration of the state, which sought to honor, keeps safe the dignity of women, and situates women in the right place that they deserve as per the civilized project of the nation and in line with our traditions and the values of our religion. On September 6, 2000, there was a planned meeting among a number of civil society organizations and representatives of UN offices in Khartoum to discuss preparations for Beijing +5 . Instead, this meeting's agenda were changed to discuss the Governor's Decree. It was clear that it affected a large number of poor women who were the breadwinners and the sole providers for their families. Most of those sell food and drinks in the streets to support their families. One of my interviews who attended this meeting said that, "this decision was unfair; we worked hard to stop it and other similar decisions as well. 
What is the difference between selling petrol or food or tea or even local wine? Has the government prepared alternative sources of living for these women? Is Islam forbidding women from working to feed their families?" .The "Women's Solidarity Network" -"WSN" was formed as an immediate reaction to the Governor's Decree including women from the women's and civil society organizations. The overall objectives of this Network were to create a joint platform of action for the civil society organizations to work for the protection of women's rights, to enhance solidarity among Sudanese women through conducting joint activities and to consolidate Sudanese women's efforts in protecting their rights. It was also decided to elevate this Network to a permanent entity to challenge all such decrees, which may come up in the future and to maintain necessary connections with the concerned international agencies and local entities. One of my interviewee said that, “...the stand that was taken by the Women's Solidarity Network was not only important in stopping the Governor's Decree. But also, it further stop the efforts of the Governor to add a very serious sentence to the Labor Law that is "women are allowed to work unless their work contradicts with Sudanese modesty and culture". Getting such a sentence approved would have created a lot of prolems as who has the authority to define Sudanese modesty and culture"

The women who formed the "WSN" benefited from the training opportunities that were available to them as members of international organizations in Khartoum. As well benefited from their participation and attendance at international conferences and workshops, one of them said that, "UN conferences and UN programs have enacted a change and created a tendency toward dealing with women's concerns: Women were able to channel their views publicly through workshops and consciousness-raising campaigns. Such activities are reflected positively on raising gender awareness in local settings about women's issues". Furthermore, different programs in international NGOs and UN agencies supported women's issues; this had its positive impact as well. One of interviewee said, "I believe these new issues around gender violence against women, and women's participation in decision-making came as a result of the international impact of the UN conferences in Nairobi, Beijing, etc. All this creates a mutual or joint understanding of women's issues". A short-term work plan was issued; smaller task groups were formed to handle different activities. A number of meetings were held with representative from different organizations and individuals, including Judges from the Ministry of Justice and representatives of civil society, including lawyers and human rights associations; representatives from the General Union of Women of Sudan, the only official governmental representative of women; academics; and supportive men. In addition, the Network called for the support of the United Nations Development Program (UNDP), the United Nations Population Fund (UNFPA), and United Nations International Children's Emergency Fund (UNICEF) in Khartoum-Sudan. Various networks joined the WSN like ; Women and Development Networks, Sudanese Women Empowerment for Peace, Female genital mutilation (FGM) Network, Population and Health Network, Poverty Network, HIV/AIDS Network, etc. (Nouh \& Badri, 2008, p. 173). One of my interviewee talked about the importance of networking among civil society organizations. She said; "There are a lot of Network organizations which get women to work together like Women from Darfur, the Platform for Women of Political Parties. Usually organizations share the chances for training and experiences and conduct joint workshops on different issues of similar concern". The Women's Solidarity Network received requests to join the networks of other civil societies and women's organizations from other regions of Sudan.

Members of the local NGOs and civil society organizations who were part of the WSN handled many workshops among their members and with the women affected by this Decree to raise awareness among women at the grass-roots level at residential areas. One of the members talked about her long experience of working in local civil society organizations. She said, "I started in late 1970 with the Babiker Badri Association for fighting harmful customs. We did a lot of work in fighting female circumcision. In the Aza Association and Peace Bridge Association, we have clear structures, we have a constitution, and each project has a coordinator, trainers, and a project writer. We are involved in many activities in a program for the development of handcrafts, fighting HIV/AIDS, the food industry, and we organize exhibitions for women's products to support them financially. In the program for peace, we organize workshops to build a culture of peace. We work among the internally displaced, women in prisons, street kids, and the youth. I believe our activities have led to empowering women".

Other Local women's rights organizations conducted workshops about Convention for the Elimination of all forms of Discrimination againstWomen to explain the constitutional rights of women. One of the women I had interviewed said, "The international documents raised human slogans without referring to the specialty of each situation. However, at the end they are good to be used as a common language and in raising awareness". The stories of my interviewees have confirmed that they had managed to use international conventions, such as the (CEDAW) and their international connections to fight for the rights of women, including the right to employment when threatened by the Decree of the Governor of Khartoum in 2000. I argue that such usage of these human rights tools has not only provided international support and legitimacy to local women's activism, but also transformed these international tools into a form that is understandable by women at the grassroots. 
Such tools have not been applied blindly, but are critically understood and subjected to local understandings and circumstances in their adaptation. The act of reaching out to the women who were affected by the Decree and the provision of immediate financial and non-financial support indicated a commitment to and direct responsibility for women at the grassroots level. The efficient use of resources available among women's civil society organizations, such as the legal services provided by women's legal offices and associations, as well as the coverage provided by women in the press, played a large role in the elevation and coverage of the activities of the Women's Solidarity Network in support of the affected women.

Immediate decisions were taken to write a memorandum condemning and disapproving of this Decree undersigned by 34 civil society organizations and voluntary associations, as well as civil society networks. This proposed memorandum was issued on September 7, 2000. This memorandum requested the immediate cancellation of the Decree and drew attention to the facts that, this Decree contradicts the International Convention of Political, Civil, Economic, Social Rights, which the Government of Sudan ratified, and the Sudan's 1998 Constitution that respect women's rights in employment. The memorandum also stressed that the women were targeted by this decision are responsible for the livelihood of their families. Copies were sent to the President of the Republic of Sudan, the Head of the Ministerial Cabinet, the Association of Sudanese Workers Union, the Ministry of Justice, and the Advisory Council for Human Rights, the General Union of Women of Sudan, and the Sudanese Daily Press. The language used in this official memo and others indicated and followed a discourse on women's rights. It stressed that the Decree violated women's rights and the Constitution of Sudan. It further responded to what was given as a justification for the Decree in terms of keeping society's traditions and religious values "safe," and confirmed the strong and united stand of all women for their rights. One of my interviewee confirmed how the WSN members benefited not only from their experiences in international agencies but also from their relationships and networks she said that, "we also meet in conferences like Beijing +5 or 10 or 15, with African and Asian women with whom we exchange experiences, for there are many similar problems. We share in cases of emergency when signing petitions in the online events as needed". Women working in the UN and international NGO offices in Khartoum also played an important role in circulating the news to their networks and providing support to the WSN. Internationally, messages were communicated through the use of the Internet and international support networks outside Sudan condemning the Decree and requesting support to pressure the government of Sudan to cancel it. This has led to what Alvarez referred to as the "public visibility of feminism" (Alvarez, 2000, p. 38), which is facilitated by the development of communications - i.e., the Internet-and made available timely international interventions in cases of violations of women's rights.

In recognition and support of all these efforts, an announcement was circulated on September 8, 2000, under the title "Sudan Blasted on Women's Ban" from Ethel Higonnet, with the African Association of Human Rights Watch in New York. It was a clear condemnation of the Decree of the Governor and its publication coincided with the visit of the President of Sudan Omer Al Bashir to New York for the UN Millennium Summit. It stated, "Human Rights Watch calls on the President of Sudan, the Foreign Minister, and the Governor of the State of Khartoum to overturn the Ban".This was a great accomplishment at the level of local and international civil society organization and community activism.

Another memorandum was also sent on September 11, 2000, signed by the National Women's Democratic Alliances, which also a member of WSN, as a step to create more local and international pressure on the Government. This memorandum confirmed this Decree contradicts international conventions that supports women's rights and considered as a betrayal of all the accomplishments of Sudanese women, gained through a long history of struggle. It further called the Governor of Khartoum to find more employment opportunities for women in need and put in place Decrees that protect them from discrimination and harassment. It requested the cancellation of this Decree and all similar discriminative similar decisions, for example the Law of Public Order that restrict women's freedom. Copies were distributed to the Representatives of the UN in Khartoum, the Representative of the Arab League, the African Union, the Sudanese Human Rights Organization, the International Labor Organization, and all local and international media.

At the legal level, three motions were presented against the Government of Sudan before the Constitutional Court from two legal offices in Khartoum with the names of women affected, and this was supported by a local women's legal NGO called "Muta'want" which is a group of women lawyers. Another motion was raised by the General Women Sudanese Union - a government-sponsored women organization — on behalf of the affected women. The Constitutional Court issued its decision, which directly stopped the execution of the Governor's Decree. The General Women Sudanese Union publishedand widely circulated the court sessionsafterwards in a booklet.

The WSN also represented how women can come together and form "transnational alliances" despite their differences to fight for their cause. The WSN included women from civil society organizations, women from political parties, and women who were part of the Islamic Government of Sudan. All of these groups have their ideological and political differences. However, what actually united them was the attack on women's right to employment. 
The fact that they were able to surpass their differences and create this alliance in a direct and immediate response is an indicator that Sudanese women are able to work collectively to oppose a movement that threatened a basic right. Badri documented this solidarity event and said, "All women in spite of their differences were opposed to the act; the act was withdrawn and the Governor changed" (Badri ,2008, p. 60). An active member of a community organization, said, "All women from different groups joined efforts against the Governor's decision, even members of the women of the government." A member of the General Women's Union- a Muslim women's government group- said, "We also stood together with other women against the Governor of Khartoum's decision which forbids women from working at hotels, oil stations, and other small businesses where those women sell food or tea in different areas. Being part of the Islamic government does not forbid us from keenly following up on women's issues and opening our eyes wide for any attacks on women's rights".

Furthermore, the fact that this case was presented to the constitutional court under the name of the Women's General Union indicated that the priority was for women's issues in this case. The Governor of Khartoum was part of the Islamic Government in Sudan and his Decision was based on the "civilized Islamic Project" promulgated by the National Congress Party and supported by the women of the General Women's Union. However, the women of the Union worked in collaboration with the other women's groups against this Decree. I argue that women's transnational activism has opened the door for women to work together on issues concerning women. The approach adopted by the women of the civil society organizations in terms of creating a coordination body and planning strategically to mobilize against the Governor's decision at the local and international levels simultaneously, indicated a high level of professionalism. The immediate steps that were taken, which were directed toward different bodies at the same time, the government, the international community, the local press, and the affected women at the grass roots level, indicate a high level of organization, consistency and ability to lead. The fact that the Decree was issued on September 4, 2000, and received international condemnation by Human Rights Watch on September 8, 2000, indicated that the campaign led by women for their rights was an international success. The resultant empowerment of grassroots movements and the increase of leadership skills among women have enhanced awareness about the importance of gender equality, not only among women but in society in general.

Despite this success, some critics argue that such alliances are scattered and isolated efforts, which cannot be counted as building a sustainable coalition among different groups of women in Sudan. However, I maintain that such alliances prove the possibility of Sudanese women's ability to work together. The question of the sustainability of such alliances requires further efforts, and is part of a continuing struggle.

\section{Conclusion}

The approach, dynamics and the means of women's struggles for their rights of employment reflect an engagement and linkage with both the local and the international concurrently. The fact that they managed to build an alliance for their rights as women despite their political differences indicates that the nature of their transnational activism satisfied both their daily basic needs as well as at their strategic goals. The intermingling between the local and the global further consolidates that the "transnational woman" of Sudan is more confident in going beyond the divisive agenda of nationalists and nationalism and strategically using all available means to support her aims, including reaching-out transnationally to sustain local rights.

Tensions which, are created at the transnational-local level as well as transnational-international level between and among women using international documents to support their rights, such as CEDAW, have open the space for resistance against women's subordination. I argue that the overall impacts of women's activism under transnationalism have resulted in the disruption of the dichotomy between the public sphere and the private sphere. The public sphere has become an open space for the international ideas of women's rights, while the private sphere has been exposed to frank challenges by women's advocates on issues around personal laws, violence against women, etc. The outcomes of these changes are still to come. When space opens for a collective engagement in imagining, the feminist project of social transformative change is then possible. Sudan has proven that women can be successful in using global feminist imaginings and subsequent gains to put pressure on their own government to enact policy changes at the national level. My research tells me that; contemporary feminist change in Sudan is being led by a transnational woman subject. This woman is sufficiently aware of her difference from her global sisters; is able to escape the repressive constructions of Sudanese nationalism through the strategic use of international legal tools, instruments, and documents; and is concomitantly reaches out in solidarity to the local and the international.

It is important to consider the complex power milieu as an essential element that helps to build solidarity and recognizes the different mechanisms used by different women as per their location against structures of oppression and subordination. This will ultimately be reflected positively in terms of social change as a primary goal of feminism. 
I asked one of the "transnational women activists",in the past, the leaders of the women's movement in Sudan were well known; now I do not hear any big names. Why? She replied, "In the past, the movement's leaders were few; that is why they shone like stars. Now the sky is full of stars, with women not only from Khartoum but also from all regions of Sudan; a leader would have to be a moon to be recognized".

\section{Author's Note}

Mawahib Bakr is a Research Program Manager at the Research Center for Islamic Legislation and Ethics-College of Islamic Studies- Hamad Bin Khalifa University

Correspondence concerning this article should be addressed to Mawahib Bakr-College of Islamic Studies - Hamad Bin Khalifa University- P.O. Box 34110 Doha, Qatar

Contact authors at: bakrmawahib@ @otmail.com - Phone: +974 66694490

\section{Bibliography}

Alvarez, S. (2009). Beyond NGO-ization? reflections from Latin America. Development,52,2 , 175-184.

Alvarez, S. (2000). Translating he Global::effects of transnational organizing on local feminist discourses and practices in Latin America. Meridians, Autumn 1,(1), 29-67.

Badri, B. (Ed.). (2008). Sudanese Women Profile and Pathways to EMpoerment. Khartoum: Ahfad University for Women.

Badri, H. (2002). Women's Movement in the Sudan. Khartoum: University of Khartoum publishing House.

Basu, A. (2000). Globalization of Local/ Localizing of the Global: Mapping Transnational Women's Movements. Meriadians , Vol 1,Autumn .

Chandra, M. T., \& Alexander, J. M. (2010). Cartograpgies of Knowledge and Poer:Tansnational Feminism as Radical Praxis. In A. L. Nagar, Critical Transnational Feminist Praxis (pp. 23-45). Sunny.

Chowdhury, E. H. (2011). Transnationalism Reversed Women Organizing agains Gender Violence in bangladesh. New York: State University of New York SUNY.

Dawalbaiet, S. (2007). About the Civil State and women's Rights in Sudan. Women in Machakos, 58-68. Khartoum: Gender Center for Research and Training.

Desai, M. (2007, Fall/Winter). The Perils and Possibilities of Transnational Feminism. Women's Studies Quarterly $35: 3 \& 4$.

El-Amin, N. A. (August 1994). The Democratic Advance and Women's Movement in the Sudan. The XVIth World Congress of the International Political Science Association (pp. 1-47). Berlin: IPSA.

Ferree, M., \& Tripp, M. (Eds.). (2006). Global Feminism: Transnational Women's Activism, Organizing, and Human Rights. New York, London: New York University Press.

Friedman, E. J. (1999, Autumn). The Effects of 'Transnationalism Reversed' in Venzuela: Assessing the impact of UN Global Conferences on the Women's Movement. International Feminist Journal of Politics 1:3 , 357-381.

Friedman, S. S. (2001). Locational Feminism: Gender, Cultural Geographies, and Geopolitical Literacy. In M. Dekoven (Ed.), Feminist Locations: Global and Local, Theory and Practice (pp. 18-36). New Brunswick; New Jersey; London: Rutgers University. Grewal, I. a. (1994). Scattered Hegemonies: Postmodernity and Transnational Feminist Practices. Minneapolis: University of Minnesota press.

Hesse-Biber, S. N., \& Leavy, P. (Eds.). (2004). Approaches to Qualitative Research: A reader on Theory and Practice. Oxford, New York: Oxford University Press.

Khagram, S., \& Levitt, P. (Eds.). (2008). The Transnational Studies Reader: Intersection and Innovations. New York, London: Routledge.

Moallem, M. (1999). Transnationalism, Feminism, and Fundamentalism. In C. Kaplan, N. Alarcon, \& M. Moallem (Eds.), Between Women and Nation: Nationalisms, Transnationalisms and the State (pp. 320-348). Durham; London: Duke University Press.

Moghadam, V. (2005). Globalizing Women: Transnational Feminist Networks. Baltimore; London: The Johns Hopkins University Press.

Naples, N. (2002). Changing the Terms: Community Activism, Globalization, and the Dilemmas of Transnational Feminist Praxis. In N. \&. Naples, Women's Activism and Globalization: Linking Local Struggles and Transnational Politics. New York \& London: Routledge.

Tripp, A. M. (2006). The Evolution of Transnational Feminism: Consensus, Conflict, and New Dynamics. In M. M. Ferree, \& A. M. Tripp (Eds.), Global Feminism: Transnational Women's Activism, Organizing, and Human Rights (pp. 51-75). New York, London: New York University.

Tripp, A. M., Casimiro, I., Kwesiga, J., \& Mungwa, A. (2009). African Women's Movements Changing Political Landscapes. Cambridge ,New York, Melboune, Madrid, Cape Town, Singapore: Cambridge University Press. 